\title{
Potential Development Management of Students in Islam
}

\author{
Moch. Charis Hidayat \\ m.charishidayat@fai.um-surabaya.ac.id \\ Muhammadiyah Surabaya University, Indonesia \\ Choirul Mahfud \\ choirul.mahfud@its.ac.id \\ Institut Teknologi Sepuluh Nopember, Indonesia
}

\begin{abstract}
This study aimed to investigate and describe the management of developing potential students based on Islamic views. This study used a qualitative method with a case study approach. The subjects of the research were Madrasah supervisors, Madrasah headmasters, and the teachers. The results of the study showed that the development of potential students when referring to the objectives of national education in particular and development, in general, is to create "Total Man" by creating human beings who has complete characteristics, harmonious, and balanced in the development of all aspects of his personality. Humans as a whole are individuals who can reach all relationships with God, with the environment or natural surroundings, with other humans in a constructive social life and with themselves. Management of the development of potential students based on Islamic views stipulates that new education will end when someone dies. Physically, seeking knowledge will end when someone dies, but the process of seeking knowledge continues to an infinite limit.
\end{abstract}

Keywords: Education in Islam, Islamic views, students' potential development

\section{Introduction}

Al-Qur'an as a guide for human life regulates life from various aspects starting from the aspects of social, economic, worship, education and so forth. In the educational aspect, Al Qur'an emphasizes the importance of studying, the purpose of education, some teaching methods and the importance of a student in the world of education. Education is kind of guidance carried out by an adult to educate persons in a period of growth till that group of persons have Islamic personality. In one way we see that education is aimed more at improving mental attitudes that will be realized in deeds, both for the needs of oneself and others. In education, it is not only the family which is the main factor of basic education but also the school or the society is also highly prioritized in educating someone.

Educators are subjects who carry out education because educators play an important role for ongoing education. As the matter of fact, educators have a major influence on the impacts of education for students which are the most important objects in education. The influence of educators is due to the actions or educational actions that are carried out only to bring students to the intended educational goals. According to Imam Al-Ghazali, children are the mandate of Allah and must be guarded and educated to achieve virtue in life and draw closer to Allah. Meanwhile, their parents will carve and shape their children into high-quality pearls and are 
loved by everyone because all babies are born in this world basically are like pearls that are formless but highly valued. So the child's dependence on the educator, including the parents, is very important.

Education is conscious guidance and helps given by educators to students to reach the maturity of physical and spiritual development. Students who are in the process of searching for life values must be fully guided by educators because according to Islamic teachings, when children are born, they are in a weak and holy state of nature, after that the surrounding nature will give color to the value of life for the religious education of students (Zuhairini, 1995). In terms of their positions, students are human beings who are in the process of development and growth according to their respective nature (Arifin, 1991). They need consistent guidance and direction to reach the optimal point of their natural abilities. Thus, in order to succeed the process of Islamic education, it must take the path of education as the process of the development of the nature of students.

Students are creatures that grow and develop. They are dynamic individuals who have certain characteristics in each part of development processes. This growth and development are natural processes occurs in human life (Desmita, 2012). The development of students has consequences for the treatment of education. In infant period, education is carried out by adults by giving more assistance to physical development, such as the help of parents to children so they can function their feet to walk. This continues until the child can control and function his organs. After that, in the kindergarten school age, the education process is not just to train his organs to function more perfectly but also to develop psychological abilities that begin to develop, for example, developing courage through games (Sanjaya, 2008). This process of education treatment will continue and have stages according to the period and the characteristics of the development of the students.

Education also plays an important role in determining the existence and development of the next generation. Therefore, Islamic education seeks to preserve, divert and transform religious and cultural values to the next generation, so that the ideal cultural-religious values can function and develop in society. The Prophet obliged all Moslems to study. This implies how important education for Muslims is. As the hadith narrated by Ibn Majah which means as follows: from Anas bin Malik said, The Messenger of Allah said, claiming knowledge is an obligation for every Muslim, (HR. Ibn Majah). Besides, some scholars, The group of Salaf said, demand knowledge from cradle to grave. In other words, studying is such an obligation for someone from his childhood until he dies.

Hadiths and sayings of ulama 'salaf are the basis of the phrase "long life education" or it can be inferred that education is a continuous process that starts from human birth to death (Roqib: 2009). This educational process includes informal and formal learning. If in Islamic education there is a continuous process in education since the child is born to die, then it can be ascertained that to facilitate the achievement of the goals of Islamic education, educators must also understand the development of students. However, a study of the development of students does not necessarily refer to the thoughts of Western psychologists because in the implementation of Islamic education, it cannot be separated from the two guidelines namely the Qur'an and the hadith of the Prophet.

\section{Methodology}


This study used a qualitative study with a case study approach. Creswell (2014) mentions that the method facilitated people to work with small groups of participants to obtain in-depth information, understanding, and wider insights on the determined topic. Besides, Creswell (2014) also says that the case study approach has focused on deep exploration of a bounded system such as an activity, an event, or a process.

\section{Research site and participants}

The key participants of this study were madrasah supervisors, headmaster, teachers, students, and staff at Sidoarjo. Creswell (2012) states that the researcher needs to pay attention to the following condition; informants who master or understand something through the enculturation process so that thing that is not only known but also comprehensible. Next, the informants who are classified as still engaged or involved in the activities being studied, who have sufficient time to be asked for information, who do not tend to convey information on the results of their own perspective, who was originally classified as quite unfamiliar with the researcher so that it was more exciting to be a kind of teacher or resource person. For research ethics, the rights of all research participants must be protected and respected. Moreover, Adherence to this principle guarantees that people will not be utilized as merely a means in achieving research objectives (Mack et al., 2005). Therefore, in this research, all sensitive personal information of the participants was marked through initials.

\section{Data collection}

We conducted semi-structured interviews in the data collection process. A semistructured interview is defined as qualitative instruments for data collection to ensure that each participant of the interview is given similar questions during the process of the interview. It allows a researcher to come into the inner worlds of the participants and gain a comprehension of their perspectives by utilizing a structured of prepared questions (Creswell, 2012; Patton, 1990). In this research, each participant was interviewed for 30 to 40 minutes and all interviews were recorded using smartphones. Triangulation, member checking, and reflexivity were used in this study (Creswell, 2012; Johnson \& Christensen, 2008; Mukminin \& McMahon, 2013) to examine the reliability and validity (trustworthiness) of the data. We conducted triangulation in this study by collecting the data from the interviews with all participants, supervisors, school principals, and teachers. To verify the accuracy of the data, we gave back the transcribed interviews data to each participant involved for what Creswell (2012) called "member checking". This was done to make sure that each of the participants agreed on the data we gained and used. We also ensured that the participants gave their permission to use the data. Creswell (2012) explained that researchers in elaborating the data must explicitly inform their biases, values, and personal interest related to the research topic, process, and research participant access. Through reflexivity, we engaged our self-reflection about the result from our own potential biases. Through reflexivity, the bias becomes more controllable. We conducted the self-reflection by conducting discussion whether we possessed bias and if so, what kind of bias we had in this research. 


\section{Data analysis}

Marshall and Rossman (1999) explain that data analysis in a qualitative study is a messy, time consuming, creative, ambiguous, and fascinating process and undoubtedly where no consensus exists for the analysis of the forms of qualitative data. In analysing the data, the interviews were recorded with a smartphone through recording application and the data then were transcribed. Next, the data were carefully analysed, re-analysed and categorized into particular themes. We did within-case analysis (Miles \& Huberman, 1994). After the interviews, the data were transcribed in the forms of verbatim. We conducted the analysis and categorized the data into themes before we did the cross-case analysis. We did re-analysis to the transcripts from all participants' information to gain the frequency of statements for each theme. We also did it to eliminate repetitive data, for example, there was one participant who made the same statement many times.

\section{Findings}

Based on the results of the qualitative data gained from the interview to the participants. We classified the data into there themes; student development, development of student's potential and management development of potential students. The themes were described as follows.

\section{Student's development}

Naturally, children need education or guidance from adults. This natural foundation can be understood from the basic needs of every child who lives in this world. Students' needs that must be fulfilled as well as various potentials and dispositions are to be educated, guided and directed so that they can actualize themselves in life. In order to make students achieve the expected teaching goals, the teaching process must be adapted to the circumstances and level of ability of students, their characteristics, interests and so forth. That is why students are the object of education system. Students are members of the community who try to develop their potentials through the learning process based on certain paths, levels and types of education. The students are the main customers who gets service in the education process. In other words, the educational process will be meaningful if done by students, and dedicated to students. Therefore, all the potentials possessed by human beings can develop self-personality and others to reach perfection (insan kamil). Besides being determined by basic aspects (fitrah), students' individual development is also influenced by teaching factors (environment).

Development of students needs the process of changing in terms of physical and psychological functions (personality, mind, knowledge and so on) of those students. The process of development runs continuously to achieve the final goal that is related to perfection and the needs of the students. Human needs are divided into two kinds: 1) primary needs, which is the need for physical body such as eating, drinking, having sex, and so on and 2) secondary needs, 
which is spiritual needs. In order to meet the needs of students, providing the appropriate material as well as providing learning activities must be adjusted to create more interesting learning activities.

The needs of students consist of 1) physical needs; this is related to physical aspects demanded in learning. For example, adequate classroom and supporting facilities. 2) spiritual needs; this is related to spiritual aspects of aspects needed to be fulfilled in the learning process, for example, students' satisfaction with all of teacher's explanations from the teacher because the explanation is comprehensible. 3) social needs; this is related to the fulfillment of the desire of the students to get along one to another and to get along with their teachers and other people. In this case, the school must be seen as a place where the students learn, adapt, associate with friends with different sexes, ethnicities, religions, social status, and skills. 4) intellectual needs; It is related to the fact that every student is not the same in terms of the aspect of skills and interest in learning.

\section{Development of student's potential}

The purpose of national education in particular and in development stage, in general, is to create "The whole Man" through human beings who are complete, harmonious and balanced in the development of all aspects of his personality. Humans as a whole are individuals who can reach total relationships with God, with the surrounding environment, with other humans in a constructive social life and with themselves. As individual person, everyone has an integrated personality by retreating mind, feelings, morals, and skills (creativity, taste and intention), physical and spiritual that develops fully.

Potential is all the possibilities or abilities that exist in an individual and during the development. There are some factors in the development of students' potential which consists of 1) the flow of Nativism. It refers to the opinion that the development of individual person is solely determined by inherited and hereditary factors, for example a person's face and his/ her behavior will develop according to the face and behavior of his/ her parents; 2) the flow of Empiricism. It means that the development of individuals is solely determined by external factors or the environment. 3) convergence flow. It means that individual development is influenced both by innate factors and by environmental factors.

\section{Management development of potential students}

Educational experts build various theories about human development. Each theory has different focus. Even the theory has grown into a kind of flow in education. Among those theories, there are three major theories; Nativism, Empiricism, and Convergence. The starting point for differences in each of these theories lies in the factors that affect human development. Whether human development is influenced by nature (nativism) or by teaching factors and environment (empiricism), or both influence one to another (convergence). As a matter of fact, Islam presents its view, called the theory of positive potential (fitrah) as the basis of human development. The basis of its conceptualization refers to the words from God in Al Qur'an and the words of the Prophet Muhammad stated in Al Hadith. God in one of His words declares: So direct your face toward the religion, inclining to truth. [Adhere to] the fitrah of Allah upon which 
He has created [all] people. No change should there be in the creation of Allah. That is the correct religion, but most of the people do not know (Ar-Ruum - 30). While in one of the Prophet's hadiths it is stated: "Every child is born in his nature (the potential to believe - Tawhid to Allah and the goodness). It was the parents who made the children Jews, Christians, or Majuzis.

The meaning contained in the verses and hadith above is that basically every human being is good, has fitrah, and his soul contains purity and good basic qualities. This view is different from the concept of human development according to Nativism, Empiricism, and Convergence. Fitrah that is carried out by a child from his/ her birth is potential so that it requires humans' efforts themselves to develop the potential into factual and actual growth. To actualize this effort, Islam provides its basic principles in the form of Islamic values to make the growth of human potential guided and directed. In this process of potential growth, the teaching factor has a very large role, even determining the form and pattern of one's personality.

Based on the conceptualization, Islamic education is expected to function as a vehicle to develop the potential of the students by following their nature. Education is the process of developing the nature of these students so that they can build their moral value which reflects their Muslim personality (akhlaqul karimah). Thus, it seems clear that Islam recognizes the role of basic factors and the way to teach children in children's development stage. However, the Islamic concept of human nature and the teaching process needed is different from the establishment of the schools commonly. Students' potential (Fitrah) which covers unity, goodness, truth, and humanity of those students with the help of educators will develop dynamically. If someone's paradigm and personality have been formed, he/she will carry out an independent process to achieve the perfection of himself/herself towards Allah, a position that is always sought by all Muslims (Roqib, 2009).

Learning process is the continuous process. If the analogy of educational achievement is reaching to the sky, it means that learning does not have limit. Learning cannot be stopped. As long as humans are still moving, education must also continue. Good potential (fitrah) will not be good if there is no dynamic movement, and the dynamics are in education. Demanding knowledge since the child stage until the person dies is a need for every Muslim to fulfill his life goals. Because learning is also theological in dimension, the efforts of Muslims to realize it will certainly be higher and more enthusiastic because there is the hope of reward and happiness hereafter. The process of getting knowledge will always continue until the person passes away. Regarding to the question about when education ends, Islam stipulates that education process will end when someone dies. Physically, seeking knowledge will end when someone dies, but the process will continue to an infinite limit because education in Islam has a transcendental value; not only as a process in the world, but also it still has meaning in the hereafter. Therefore, education in an Islamic perspective becomes unlimited (Mahfud, 2016; Mahfud, 2019; Rahmawati, 2018).

As stated earlier, education aims to equip students with high academic abilities to continue their studies to a higher level. This means that the ability possessed by students after they finish their education consists of the following sub-abilities 1) understanding of religious spirituality that is believed by students and the habit of practicing that religious spirituality in everyday life; 2) mastering the comprehensive basic framework of various disciplines; 3) owning the willingness, habits, and ability to access, to study, to choose, and to organize information by 
utilizing various sources, including electronic/computer sources; 4) mastering the communication skills and ability to interact respectfully in a diverse community; 5) owning the ability to work with other people; 6) understanding, developing, and renewing the potential of oneself, as well as the ability to make the best decisions about the future; 7) owning the ability to enjoy, appreciate and express the values of beauty.

Characteristics of students are the overall behavior and abilities that exist in students as a result of nature and social environment so that it determines the pattern of activities in achieving their love. Thus, the determination of learning objectives must be linked or adjusted to the conditions or characteristics of the learners themselves. Three things need to be considered in the characteristics of students are as follows: 1) characteristics or circumstances relating to initial abilities such as intellectual abilities, ability to think, say things related to psychomotor and other aspects; 2) characteristics related to background and social status (socio-culture); and 3) characteristics relating to personality differences such as attitudes, feelings, interests, and others. Knowledge of the characteristics of these students has a significant significance in teaching and learning interactions. Especially for teachers, information about the characteristics of students will always be very useful in selecting and determining better teaching patterns, which can guarantee the ease of learning for each student (Mukminin, 2012; Yahiji et.al., 2019).

Facts about learning that are less student-based and have an impact on learning ineffectiveness, are experienced by some famous people: 1) Winston Churchill was one of the greatest leaders and orators of the 20th century, he scored poorly in his assignments and tests in school and stuttered in talk; 2) Albert Einstein, the greatest scientist of his time, failed in mathematics when he was still in high school; 3) Thomas Alva Edison was beaten at school because his teacher thought he was confused, and asked too many questions; and 4) Woodrow Wilson, a President of the United States, could not read until he was eleven years old. They had the same treatment in learning, which was to have a learning process that did not match the learning style. Thus, commonly, students with low achievement are young people whose learning styles do not match the style of teaching at school. The key to success in learning is knowing each person's learning styles; visual, audio, and kinesthetic style, accepting one's strengths and weaknesses, and as much as possible adjusting personal preferences in each learning situation.

Learning experts agree, that "The characteristics of students are one of the most influential variables in learning. Any learning model that is developed or any strategy chosen for learning needs must be based on individual characteristics ". Opinions from other experts also say" Characteristics of students are defined as aspects or qualities of individual students such as talent, learning motivation, and initial abilities that have been learned and possessed and are useful as a foothold in choosing the optimal learning strategy.

\section{Discussion}

Students are one of the human components that occupy a central position in the teaching and learning process. In the teaching-learning process, students are parties who have goals and want to achieve those optimally. So in the teaching and learning process, there are several things that needs to be considered: 1) the students; their conditions and abilities; 2) the needed materials; 3) the right way to act; and 4) the suitable and supportive tools and facilities. That is 
why students are the subject of learning. Thus, several things must be fulfilled by students as learning subjects, such as 1) understanding and accepting physical conditions; 2) getting a satisfying relationship with their peers; 3) achieving more "mature" relationships with adults; 4) achieving emotional maturity; 5) achieving intellectual maturity; 6) forming a view of life; and 7) preparing to establish household.

The Qur'an which discusses the importance of a student is At Taubah in Ayah 122, which states Nor should the Believers all go forth together: if a contingent from every expedition remained behind, they could devote themselves to studies in religion, and admonish the people when they return to them,- that thus they (may learn) to guard themselves (against evil). (At Taubah;122). In the surah At-Taubah verse 122 it can be inferred that some people are ordered to seek knowledge and others are ordered to strive in the way of Allah because actually, jihad is fardhu kifayah for humans. The meaning of fardhu kifayah is if in a nation or state where some people of that state go to carry out jihad, then the other sins will be lost. one of fardhu kifayah activities is jihad, that is upholding the truth, upholding the law, separating the hostile and so on. Meanwhile, fard 'ain is an obligation that must be carried out by every Muslim who is baligh, such as praying, conducting zakat, and fasting. (Wahbah Ar-Rahili,1991)

As for those who returned after seeking knowledge, they were obliged to provide knowledge and preach to others because seeking knowledge invited people to the right path. Demanding knowledge is the greatest virtue and has the noblest position. Thus, Learning has an important role in life. By learning people become smart, they will know everything they learn. Without learning, people will not know anything. Besides, learning can increase knowledge of both theory and practice, and learning is also considered as worship to God. The person who learns something whose is truly accompanied by sincere intentions, then he will get a lot of rewards. Learning is also considered as actual practice that can bring forgiveness from Allah S.W.T.

All human beings are born in a state of fitrah. Some scholars say that nature is religious potential. As the hadith of the Prophet Muhammad, states: From Abi Hurairah RA who said that the Prophet SAW. said "Every child is born according to fitrah (potential for Muslim). Furthermore, it was the parents who turned their children into a Jew, or Christian, or like animals gave birth to animals, did you see any shortcomings in Him?. From the hadith, there are two things that can be understood: 1) every human being has the potential, both the potential for being a good person and the potential to be a bad person; 2) the potential that can be influenced by the environment, especially parents because they are the first persons to play their role in making their children become Jews, Christians and others. The concept of hadith is under the theory of convergence in the development of students, who argue that every child is born in its development stage which is influenced by heredity and environment. That is, every child will be influenced by his offspring, for example, a child who is born from a good family, of course, he will be a good child and influenced by his environment.

Besides, another hadith From Anas states "I listened to the Messenger of Allah" Says "glorify your children and make their education good". The hadith is indeed a command to parents to glorify and educate their children well, but we can also understand from the hadith directed to students, where a student must have dignity. Thus, the education process for children means educating their children by giving examples, choosing educational institutions that are 
good for the development of their children and choosing peers who will not plunge their children into a path that is not good.

Another hadith was narrated by Abu Musa RA that the Prophet Muhammad had said: "Verily the parable of the guidance and knowledge of Allah SWT that made me as a messenger was like rain falling to Earth. Between the Earth, there is fertile land that absorbs water and piece of land that has green grass thrives. There is also land that does not grow anything, even though the land is full of water. Allah SWT lowers the water so that humans can drink it, eliminate thirst, and plant the empty land. There is also a group of people who have arid land that has no water and nothing grows on the land. The hadith reflects someone who has the knowledge of the religion derived from Allah SWT and wants to take advantage of something that has caused me to be sent by Allah SWT and then the person learns and does it. And like someone who is not at all interested in what has caused me to be sent by Allah SWT. He did not get guidance from Allah SWT, so I became His messenger." This hadith describes the difference between humans in their ability that is the ability to learn, understand and remember. According to Muhammad Uthman Najati, these three abilities are classified in terms of intellect. Based on this hadith, it can be understood that human intellect can be classified in three groups: 1) Like fertile land, which means people in this group can learn, memorize, and teach the knowledge that they have to others; 2) Like arid land, which means people in this group can maintain the knowledge and teach knowledge to others, but the knowledge he has is not beneficial to himself. Like barren land, which means that people in this group are not interested in teaching others.

Thus as an educator, he must indeed be able to understand the differences in his students' intelligence so that he can choose the right method, approach, and media to make all students digest the subject matter well. This can be done by educators by applying varied learning methods and diverse media. Finally, differences among students need to be understood by an educators. As an educator, he must be able to show patience, sincerity, and love without saving resentment.

\section{Conclusion}

Development of students is the process of changing physical and psychological functions (personality, mind, knowledge and so on) of students who are continuously happened and related to perfection. Development of potential students when referring to the objectives of national education in particular and development in general is to create "Whole Man" by means of human beings who are complete, harmonious and balanced in the development of all aspects of their personality. Humans as a whole are individuals who can reach all relationships with God, with the surrounding environment with other humans in a constructive social life and with themselves. The management of the development of potential students is based on Islamic views which stipulates that new education will end when someone dies. Physically, seeking knowledge will end when someone dies, but the process continues to an infinite limit. It is because education in Islam has a transcendental value; not only process in the world, but also it still has meaning in the hereafter.

\section{References}


Arifin, H.M. (1991). Ilmu Pendidikan Islam. Jakarta: Bumi Aksara.

Ar-Rahili, Wahbah. (1991). At-Tafsir Al-Muniir (Fil'aqidah Wasyari'ah Walmanhaj). Beirut, Libanon: Darul Fikri Al-Ma'ashir.

Aldo Redho Syam, Moch, Charis Hidayat, (2019). Peran Bagian Public Relations Dalam Meningkatkan Reputasi Lembaga Pendidikan Di Era Otonomi Pendidikan, Tadarus : Jurnal Pendidikan Islam, Vol 8, No. 1

Budiningsih, Asri. (2004). Pembelajaran Moral. Jakarta: Rineka Cipta.

Creswell, J. W. (2012). Educational research. Planning, conducting, and evaluating quantitative and qualitative research. Thousand Oaks, CA: Sage Publications.

Creswell, J. W. (2014). A concise introduction to mixed methods research. Thousand Oaks, CA: Sage Publications.

Desmita. (2012). Psikologi Perkembangan Peserta Didik. Bandung: Remaja Rosdakarya.

Mahfud, Choirul. (2016). Politik Pendidikan Islam di Indonesia. Yogyakarta: Pustaka Pelajar. (2018), Chinese Muslim Community Development in Contemporary Indonesia: Experiences of PITI in East Java, Studia Islamika 25 (3).

(2019). Evaluation of Islamic Education Curriculum Policy in Indonesia, Premiere Educandum: Jurnal Pendidikan Dasar dan Pembelajaran 9 (1), 34-43

Mack, N., Woodsong, C., MacQueen, K. M., Guest, G., \& Namey, E. (2005). Qualitative research methods: a data collectors field guide. New York: Sage

Marshall, C., \& Rossman, G. B. (1999). The "what" of the study: Building the conceptual framework. Designing Qualitative Research, 3, 21-54.

Miles, M. B., \& Huberman, A. M. (1994). Qualitative data Analysis: An expanded sourcebook. San Francisco, CA: Sage Publications, Inc.

Mukminin, A. (2012). Acculturative experiences among Indonesian graduate students in US higher education: Academic shock, adjustment, crisis, and resolution. Excellence in Higher Education Journal, 3(1), 14-36.

Mukminin, Amirul, Habibi, Prasojo, Idi, Hamidah. 2019. Curriculum Reform in Indonesia: Moving from an Exclusive to Inclusive Curriculum. Center for Educational Policy Studies Journal 9 (2), 53-72

Rahmawati, Yahiji, Mahfud, Choirul, Alfin, Koiri. (2018). Chinese ways of being good Muslim: from the Cheng Hoo Mosque to Islamic education and media literacy, Indonesian Journal of Islam and Muslim Societies 8 (2), 225-252.

Ramayulis. (2004). Ilmu Pendidikan Islam. Jakarta: Kalam Mulia.

Roqib, Moh. (2009). Ilmu pendidikan Islam. Yogyakarta: LKiS Yogyakarta.

Sanjaya, Wina. (2008). Perencanaan dan Desain Sistem Pembelajaran. Jakarta: Kencana.

Uhbiyati, Nur. (1998). Ilmu Pendidikan Islam (IPI) Untuk IAIN, STAIN, PTAIS. Bandung: Pustaka Setia.

Yahiji, K., Mahfud, C., \& Mu'ammar, M. A. (2019). Vocational Education in Indonesia Facing ASEAN Economic Community. Indonesian Research Journal in Education |IRJE|, 3 (1), 168-176.

Zuhairini. (1995). Filsafat Pendidikan Islam. Jakarta: Bumi Aksara. 